\title{
Targeting to porcine sialoadhesin receptor improves antigen presentation to $T$ cells
}

\author{
Concepción Revilla*, Teresa Poderoso, Paloma Martínez, \\ Belén Álvarez, Laura LóPEZ-Fuertes, Fernando Alonso, \\ Angel EZQUERRA, Javier DoMíngueZ
}

Dpto. Biotecnología, Instituto Nacional de Investigación y Tecnología Agraria y Alimentaria (INIA), 28040, Madrid, Spain

(Received 10 July 2008; accepted 10 December 2008)

\begin{abstract}
Antibody-mediated targeting of antigen to specific antigen presenting cells (APC) receptors is an attractive strategy to enhance $\mathrm{T}$ cell immune responses to weak immunogenic antigens. Here, we describe the characterization of two monoclonal antibodies $(\mathrm{mAb})$ against different epitopes of porcine sialoadhesin $(\mathrm{Sn})$ and evaluate in vitro the potential of targeting this receptor for delivery of antigens to APC for T cell stimulation. The specificity of these mAb was determined by amino acid sequence analysis of peptides derived from the affinity purified antigen. Porcine Sn is expressed by macrophages present in the border between white and red pulp of the spleen and in the subcapsular sinus of lymph nodes, an appropriate location for trapping blood and lymph-borne antigens. It is also expressed by alveolar macrophages and monocyte-derived dendritic cells (MoDC). Blood monocytes are negative for this molecule, but its expression can be induced by treatment with IFN- $\alpha$. MAb bound to $\mathrm{Sn}$ is rapidly endocytosed. MAb to sialoadhesin induced in vitro $\mathrm{T}$ cell proliferation at concentrations 100-fold lower than the non-targeting control $\mathrm{mAb}$ when using $\mathrm{T}$ lymphocytes from pigs immunized with mouse immunoglobulins as responder cells and IFN- $\alpha$ treated monocytes or MoDC as APC, suggesting a role of sialoadhesin in antigen uptake and/or delivery into the presentation pathway in APC.
\end{abstract}

sialoadhesin / monoclonal antibody / macrophage / antigen-targeting / swine

\section{INTRODUCTION}

Sialoadhesin (Sn), also known as CD169 or Siglec-1, is a membrane protein, member of the family of sialic acid binding immunoglobulin-like lectins (Siglec), which contains 17 Ig-like domains in its extracellular region, with the sialic acid binding region localized within the membranedistal domain [33]. This molecule is mainly expressed by specific subpopulations of tissue macrophages $[9,13,16,21]$. Some dendritic cells (DC) located in lymph nodes [1], monocytes during inflammatory processes $[21,36]$, and in vitro monocytes-derived DC (MoDC) [27] have also been shown to

* Corresponding author: crevilla@inia.es express this molecule. Cytokines and growth factors regulate $\mathrm{Sn}$ expression, although remarkable differences have been reported between species [21, 30, 41]. Recently, it has been shown that IFN- $\alpha$ induces $\mathrm{Sn}$ expression in porcine monocytes and alveolar macrophages [14].

Unlike other members of the Siglec family that mediate inhibitory functions, $\mathrm{Sn}$ lacks immunoreceptor tyrosine-based inhibitory motifs (ITIM) in its short cytoplasmic tail [12]. It appears to function as a macrophage accessory molecule in a variety of cell to cell and cell to extracellular matrix interactions [10, 33]. Preliminary studies suggest a role of this molecule in myelopoiesis [10, 11]. However, more recent data obtained from Sn knockout mice support 
a role for this receptor in the modulation of inflammatory and immune responses $[23,34]$.

$\mathrm{Sn}$ is involved in the uptake of different pathogens in a sialic acid dependent manner $[25,31]$. In swine, it has been shown to play a role as an endocytic receptor in the attachment and entry of Porcine Reproductive and Respiratory Syndrome Virus (PRRSV) in alveolar macrophages [42], with its Nterminal domain identified as the virus binding domain [15].

Targeting of antigens to antigen presenting cells (APC) by fusing them to $\mathrm{mAb}$ that recognize receptors expressed on these cells, represents an attractive strategy to enhance the immunogenicity of weak immunogenic antigens. A variety of receptors have been successfully evaluated in the murine model for targeting antigens [39]. However, only a few reports, mostly based on the use of ligands to CD40 or CD80/86, describe the use of this strategy in domestic livestock species [7, 18, 29,38].

In this study we describe two mAb to porcine $\mathrm{Sn}$ and analyze the expression of this molecule in porcine tissues, its regulation by cytokines and its potential as an antigen targeting receptor. Porcine $\mathrm{Sn}$ is expressed in some subsets of tissue macrophages and in MoDC. Blood monocytes do not express this molecule but it can be induced by IFN- $\alpha$. To explore if antigen targeting to Sn leads to an enhancement of $\mathrm{T}$ cell responses, we immunized pigs with mouse Ig and used either IFN- $\alpha$ treated monocytes or MoDC as APC, to compare in vitro the $\mathrm{T}$ cell proliferative response elicited by our $\mathrm{mAb}$ to $\mathrm{Sn}$ with that of control $\mathrm{mAb}$. Both mAb to $\mathrm{Sn}$ induced $\mathrm{T}$ cell proliferation at concentrations 100-fold lower than control $\mathrm{mAb}$, suggesting a role of $\mathrm{Sn}$ in antigen uptake and/or delivery to the $\mathrm{Ag}$ presentation pathway. Altogether these results provide a novel antigen targeting strategy for direct in vivo evaluation.

\section{MATERIALS AND METHODS}

\subsection{Animals and cells}

Large-White outbred pigs were used as cell donors. Peripheral blood mononuclear cells (PBMC) and granulocytes were isolated as described [20]. Porcine alveolar macrophages were collected by alveolar lavage with PBS [3]. Cells were resuspended in RPMI 1640 medium containing $10 \%$ foetal calf serum (FCS), $2 \mathrm{mM}$ L-glutamine, $5 \times 10^{-5} \mathrm{M}$ 2-mercaptoethanol and $30 \mu \mathrm{g} / \mathrm{mL}$ gentamicin (complete medium).

Four-month old pigs $(n=4)$ were immunized i.m. 3 times at 3 week intervals with $1 \mathrm{mg}$ of a pool of mouse Ig (Sigma, St. Louis, MO, USA), first in complete Freund adjuvant and for the two subsequent immunizations in incomplete adjuvant.

The reported experiments were executed in full compliance with guidelines by the ethical committee of the Institute.

\subsection{Antibodies}

The hybridoma secreting anti-Sn mAb 1F1 was derived from a fusion of spleen cells from a BALB/c mouse immunized with porcine MoDC with SP2/0 myeloma cells, using established protocols [28]. Generation of 3B11 mAb secreting hybridoma has been previously reported [4].

Isotypes of $\mathrm{mAb}$ were determined by ELISA, using rabbit anti mouse heavy and light chain antisera and a peroxidase-conjugated goat antirabbit Ig (Bio-Rad, Hercules, CA, USA). 3B11 and $1 \mathrm{~F} 1 \mathrm{mAb}$ were of $\mathrm{IgG}_{1}$, gא and $\mathrm{IgG}_{2 \mathrm{a}}$, $\kappa$ isotypes respectively. For labeling, mAb were purified from supernatant by affinity chromatography on Protein G-Sepharose CL4B (Pharmacia, Uppsala, Sweden). Biotinylation of $\mathrm{mAb}$ was performed using standard protocols; mAb were labeled with Alexa Fluor 488 dye following the manufacturer's protocol (Molecular Probes, Carlsbad, CA, USA).

MAb to CD3 (BB23-8E, IgG2b) was kindly provided by $\mathrm{M}$. Pescovitz (Indiana University, Indianapolis, IN, USA), to CD8 $\alpha$ (76-2-11, IgG2a) by J. Lunney (USDA, Beltsville, MD, USA) and to CD11R1 (MIL-4, IgG1) by K. Haverson (University of Bristol, Bristol, UK).

$\mathrm{MAb}$ to porcine CD172a (BL1H7, IgG1), CD45RA (3C3/9, IgG1), SLAIIDR (1F12, IgG2b) and CD11R3 (2F4/11, IGg1) were produced in our laboratory.

\subsection{Flow cytometry}

For single staining, cells were incubated with hybridoma supernatants for $30 \mathrm{~min}$ at $4{ }^{\circ} \mathrm{C}$. After two washes in FACS buffer (PBS containing $0.1 \%$ BSA and $0.01 \%$ sodium azide), cells were incubated with FITC-conjugated rabbit $\left(\mathrm{Fab}^{\prime}\right)_{2}$

Page 2 of 15 (page number not for citation purpose) 
anti-mouse Ig (Dako, Glostrup, Denmark). Subsequently, cells were washed twice and then fixed in $0.1 \%$ formaldehyde prior to analysis on the cytometer. Irrelevant isotype-matched antibodies were used as controls. Ten thousand cells were acquired.

In cross-blocking experiments, alveolar macrophages were incubated $20 \mathrm{~min}$ at $4{ }^{\circ} \mathrm{C}$ with $1 \mathrm{~F} 1,3 \mathrm{~B} 11$ or irrelevant $\mathrm{mAb}$ supernatants. Thereafter, the biotinylated 3B11, Alexa 488 1F1 or irrelevant $\mathrm{mAb}$ were added for an additional $20 \mathrm{~min}$. Cells were washed and the biotinylated $\mathrm{mAb}$ were developed with streptavidin-PE. Then, they were fixed in $0.1 \%$ formaldehyde and analyzed in the cytometer. Twenty thousand cells were acquired.

\subsection{Immunohistochemical and immunofluorescence analyses on tissue sections}

Tissues were snap frozen in isopentane/liquid nitrogen and stored at $-70{ }^{\circ} \mathrm{C}$. Frozen sections of $6 \mu \mathrm{m}$ were fixed in cold acetone for $10 \mathrm{~min}$ and then washed with PBS.

For immunohistochemical analyses, sections were stained with monoclonal antibodies by an indirect immunoperoxidase technique, as previously described [17]. Briefly, frozen sections were incubated for $90 \mathrm{~min}$ at room temperature with hybridoma supernatants. After washing in PBS, sections were incubated with a $1 / 40$ dilution of a polyclonal rabbit anti-mouse Ig conjugated with peroxidase (Dako) for $60 \mathrm{~min}$. After extensive washing with PBS, sections were incubated for $5 \mathrm{~min}$ in a solution of $0.6 \mathrm{mg} / \mathrm{mL}$ diaminobenzidine (Sigma) and $0.02 \%$ hydrogen peroxide in PBS. Finally, they were washed with water, counterstained with hematoxilin, dehydrated and mounted with DePex (Serva, Heidelberg, Germany).

For immunofluorescence analyses, sections were blocked $20 \mathrm{~min}$ with $10 \%$ normal goat serum and incubated $60 \mathrm{~min}$ at room temperature with primary monoclonal antibodies. After washing in PBS, sections were incubated for $60 \mathrm{~min}$ with a polyclonal goat anti-mouse Ig conjugated with Rhodamine Red-X (Molecular Probes). Tissue sections were washed and blocked $30 \mathrm{~min}$ with $10 \%$ normal mouse serum, and then they were stained with Alexa 488 labeled $1 \mathrm{~F} 1 \mathrm{mAb}$ in the presence of $5 \%$ normal mouse serum. Finally, sections were washed with PBS and mounted with FluorSave (Calbiochem, San Diego, CA, USA).
Slides were examined on a Leica DM IRE2 confocal microscope (Heidelberg, Germany).

\subsection{Western blotting}

Alveolar macrophages $\left(5 \times 10^{7}\right)$ were washed twice with PBS and solubilized in $0.5 \mathrm{~mL}$ lysis buffer $(10 \mathrm{mM}$ Tris- $\mathrm{HCl}, 150 \mathrm{mM} \mathrm{NaCl}, 1 \mathrm{mM}$ EDTA, $1 \%$ NP40, pH 7.4, $1 \mathrm{mg} / \mathrm{mL}$ BSA, $1 \mathrm{mM}$ PMSF and $10 \mu \mathrm{g} / \mathrm{mL}$ aprotinin) for $1 \mathrm{~h}$ at $4{ }^{\circ} \mathrm{C}$. After centrifugation at $12000 \mathrm{~g}$ for $30 \mathrm{~min}$, the supernatant was mixed with the sample buffer, and run on a $7.5 \%$ SDS-PAGE gel under reducing and non-reducing conditions. The separated proteins were transferred to nitrocellulose. Free binding sites on nitrocellulose were blocked with PBS-2\% BSA. Thereafter, nitrocellulose strips were incubated with hybridoma supernatants for $1 \mathrm{~h}$ at room temperature, followed by $1 \mathrm{~h}$ incubation with a peroxidaselabeled rabbit anti-mouse Ig (Dako). Peroxidase activity was visualized using the ECL detection assay (Amersham, Buckinghamshire, UK).

\subsection{Immunoprecipitation analysis}

Alveolar macrophages $\left(5 \times 10^{7}\right)$ were washed three times in PBS and resuspended in $5 \mathrm{~mL}$ PBS. Sulfo-NHS-biotin (Pierce, Rockford, IL, USA) $(0.4 \mathrm{mg} / \mathrm{mL}$, final concentration) was added to the cells and incubated for $15 \mathrm{~min}$ at $4{ }^{\circ} \mathrm{C}$. After washing three times with PBS, cells were lysed with $0.5 \mathrm{~mL}$ lysis buffer. The lysate was pre-cleared twice with $50 \mu \mathrm{L} 25 \%$ (v/v) suspension of protein G-Sepharose (Pharmacia) in lysis buffer, and then incubated with the different $\mathrm{mAb}$. Three hundred $\mu \mathrm{L}$ of hybridoma supernatant were added to $100 \mu \mathrm{L}$ lysate and incubated for $2 \mathrm{~h}$ at room temperature. Then, $40 \mu \mathrm{L} 25 \%$ (v/v) suspension of protein GSepharose was added and incubated for $1 \mathrm{~h}$ with gentle mixing. Beads were washed three times with lysis buffer, boiled in electrophoresis sample buffer under reducing and non reducing conditions, and the supernatants were run on a 7.5\% SDSPAGE and transferred to nitrocellulose. Filters were incubated with streptavidin-peroxidase (Pierce) and the bands visualized with the ECL detection assay (Amersham).

\subsection{Purification and partial sequence analysis of 3B11 antigen}

Twelve $\mathrm{mg}$ of $\mathrm{mAb} 3 \mathrm{~B} 11$ were coupled to $2.5 \mathrm{~mL} \mathrm{CNBr}$-activated Sepharose $4 \mathrm{~B}$ beads (Pharmacia), according to the indications of the 
manufacturer. Alveolar macrophage lysates were obtained from $1 \times 10^{9}$ cells. Lysis was performed at $10^{8}$ cells $/ \mathrm{mL}$ for $1 \mathrm{~h}$ at $4{ }^{\circ} \mathrm{C}$, in $1 \%$ Nonidet P-40, $50 \mathrm{mM}$ Tris $\mathrm{pH} 8,150 \mathrm{mM} \mathrm{NaCl}, 5 \mathrm{mM}$ EDTA, $0.1 \mathrm{mM}$ PMSF, $10 \mu \mathrm{g} / \mathrm{mL}$ aprotinin and $10 \mathrm{mM}$ iodacetamide. Lysates were precleared by incubation for $24 \mathrm{~h}$ with normal mouse IgG-coupled Sepharose beads. Precleared lysates were incubated for an additional $24 \mathrm{~h}$ with 3B11 mAb-coupled beads. After that, beads were washed several times with the buffer used for lysis and finally with PBS. The adsorbed fraction was eluted from the beads by adding $50 \mathrm{mM}$ diethylamine $\mathrm{pH} 11$. The eluted fraction was dialyzed against $10 \mathrm{mM}$ ammonium bicarbonate $\mathrm{pH} 8$, concentrated by lyophilization and subjected to $7.5 \%$ SDS-PAGE. The main band, with an apparent molecular weight of $190 \mathrm{kDa}$, was excised and digested with trypsin. The resulting peptides were separated by HPLC, and subjected to Edman degradation on an Applied Biosystem 473A pulse liquid phase protein sequencer (Applied Biosystem, Carlsbad, CA, USA). Peptide identities were searched on SwisProt, EMBL and GeneBank databases, using the Blast analysis program ${ }^{1}$.

\subsection{Monocyte isolation and culture conditions}

Monocytes were isolated from PBMC using the magnetic cell separation system of Miltenyi Biotec (Bergisch Gladbach, Germany). First, PBMC were incubated with an antibody cocktail containing anti-CD3, anti-CD45RA and anti-CD8 $\alpha$, and after $30 \mathrm{~min}$ at $4{ }^{\circ} \mathrm{C}$ washed with PBS containing $5 \%$ FCS and 2 mM EDTA. Subsequently, anti-mouse Ig magnetic microbeads were added and incubated for $15 \mathrm{~min}$ on ice. Then, cells were washed and passed through a MACS CS separation column (negative selection). The effluent fraction was collected and analyzed by flow cytometry resulting in $\geqslant 90 \%$ pure population according to the expression of CD172a.

Freshly isolated monocytes were cultured at $2.5 \times 10^{6}$ cells $/ \mathrm{mL}$ in complete medium with different stimuli or in medium alone for 24 or $48 \mathrm{~h}$. Porcine recombinant IFN- $\gamma(400 \mathrm{U} / \mathrm{mL})$ and IFN- $\alpha(0.8 \mathrm{U} / \mathrm{mL})$ were generously provided by F. Lefevre (INRA, France); recombinant porcine IL10 (50 ng/mL), IL4 (50 ng/mL) and GMCSF $(50 \mathrm{ng} / \mathrm{mL})$ were obtained from BioSource (Carlsbad, CA, USA); porcine serum $(20 \%)$ was

$\overline{{ }^{1} \text { http://blast.ncbi.nlm.nih.gov }}$

Page 4 of 15 (page number not for citation purpose) purchased from Harlan Sera-Lab (Leicestershire, UK). After culture, cells were harvested, stained as indicated and analyzed by flow cytometry.

For differentiation of blood monocytes into DC, monocytes were cultured in complete medium supplemented with recombinant porcine IL4 $(50 \mathrm{ng} / \mathrm{mL})$, GM-CSF $(50 \mathrm{ng} / \mathrm{mL})$ and IFN- $\alpha$ $(0.8 \mathrm{U} / \mathrm{mL})$ for 7 days as described for human and porcine cells $[24,35]$.

\subsection{Internalization assay}

Alveolar macrophages were incubated with Alexa 488 -labeled $1 \mathrm{~F} 1 \mathrm{mAb}$ for $30 \mathrm{~min}$ at $4{ }^{\circ} \mathrm{C}$, without azide. After washing, cells were cultured at $37{ }^{\circ} \mathrm{C}$ for different times, and then treated or left untreated with a buffer containing $0.5 \%$ acetic acid, $0.5 \mathrm{M} \mathrm{NaCl} \mathrm{pH} 2.8$ (low $\mathrm{pH}$ buffer) for $15 \mathrm{~s}$ to disrupt the surface mAb-Sn interactions. We used cells labeled with $1 \mathrm{~F} 1 \mathrm{mAb}$ at $4{ }^{\circ} \mathrm{C}$ in the presence of $0.01 \%$ azide, and then treated or not with the low $\mathrm{pH}$ buffer as controls. Subsequently, the cells were washed, fixed in $0.1 \%$ formaldehyde and analyzed in the cytometer. An irrelevant isotypematched Alexa Fluor 488 labeled mAb was used to determine background staining.

\subsection{0. $T$ cell proliferation assay}

For proliferation assays, $2 \times 10^{5} \mathrm{~T}$ cells, enriched from PBMC by passing through a nylon wool column (Polysciences, Warrington, PA, USA), were mixed with monocytes cultured $24 \mathrm{~h}$ with IFN- $\alpha$ or MoDC and incubated with different concentrations of anti-Sn or control mAb. Cultures were run for 4 days at $37^{\circ} \mathrm{C}$ with $5 \% \mathrm{CO}_{2}$, then $1 \mu \mathrm{Ci}$ ${ }^{3} \mathrm{H}$-thymidine was added per well and $18 \mathrm{~h}$ later cells were harvested and ${ }^{3} \mathrm{H}$-thymidine uptake was measured by liquid scintillation counting.

\section{RESULTS}

\subsection{Monoclonal antibodies $3 \mathrm{~B} 11$ and $1 \mathrm{~F} 1$ recognize porcine $S n$}

Hybridomas producing mAb 3B11 and $1 F 1$ were derived from two independent fusions using as immunogen either porcine alveolar macrophages or MoDC respectively. Both $\mathrm{mAb}$ reacted with alveolar macrophages and MoDC, while blood lymphocytes, monocytes 
A)

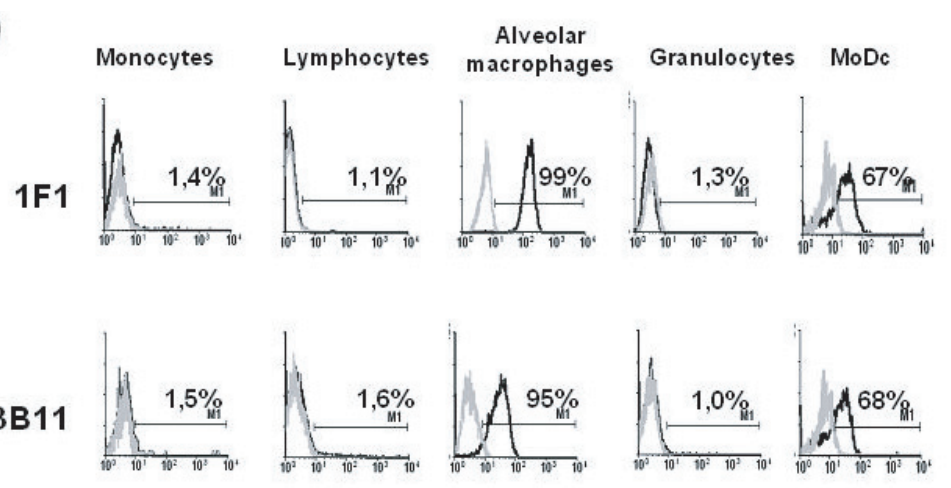

B)
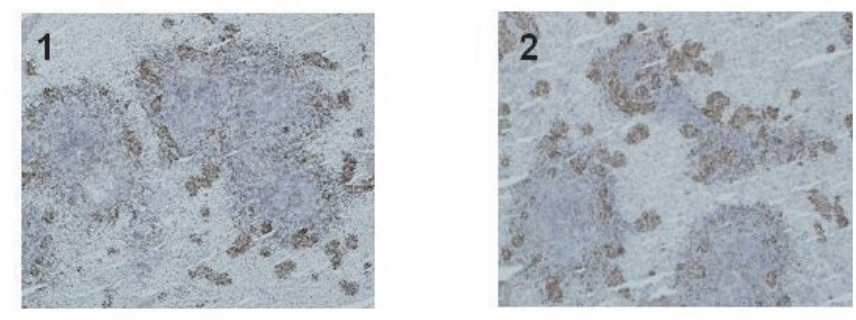

C)
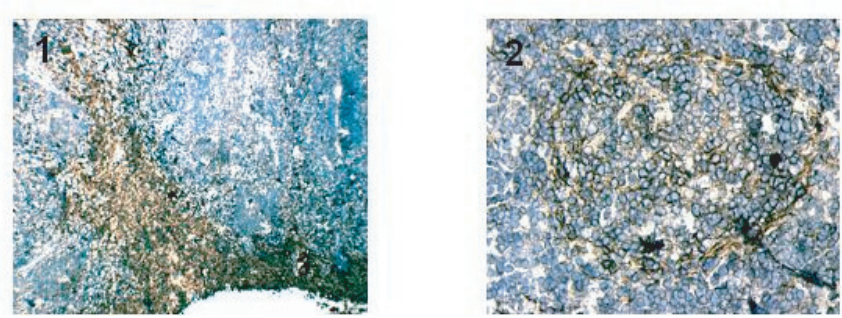

Figure 1. (A) MAb $1 F 1$ and 3B11 recognize an antigen expressed in alveolar macrophages and MoDC. Cells were labeled with $1 \mathrm{~F} 1$ or $3 \mathrm{~B} 11 \mathrm{mAb}$ (black histograms) or with irrelevant isotype-matched mAb (grey histograms). Results are representative of five independent experiments. (B) In the spleen, staining with 1F1 (1) and 3B11 (2) mAb appears associated with the walls of the ellipsoidal vessels that surround the islands of white pulp. (C) In lymph nodes, the antigen was detected in the subcapsular sinus and medullary cords (1) and in the periphery of follicles and some follicular cells (2). (A color version of this figure is available at www.vetres.org.)

and granulocytes were not stained (Fig. 1A). Tissue distribution of the antigen recognized by these mAb was analyzed by immunohistochemical staining of different tissues. The pattern of staining was similar for both $\mathrm{mAb}$. In the spleen, the staining appeared mainly located in the border between white and red pulp and associated with the walls of the ellipsoidal vessels (Fig. 1B). In lymph nodes, the antigen was detected in subcapsular and medullary sinuses, but also in the periphery of follicles, with some positive cells inside the follicles (Fig. 1C).

Two-color immunofluorescence analysis by confocal microscopy of frozen sections showed that in the spleen (Figs. 2a-2c) and lymph nodes (Figs. 2d, 2e), most $1 \mathrm{~F} 1^{+}$cells expressed the myeloid marker

(page number not for citation purpose) Page 5 of 15 
(a)

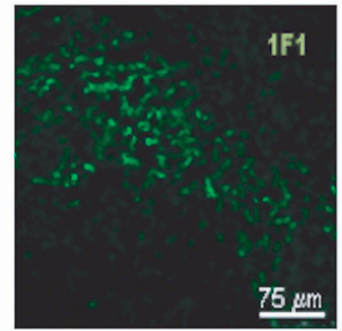

(b)

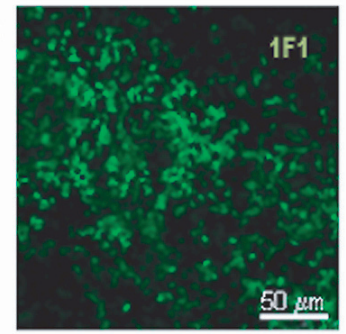

(c)

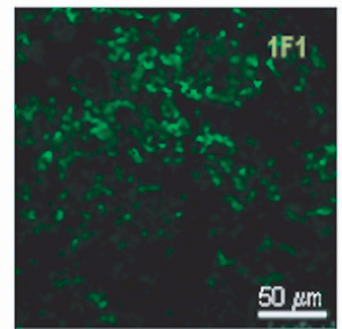

(d)

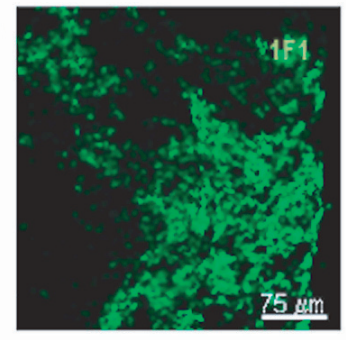

(e)

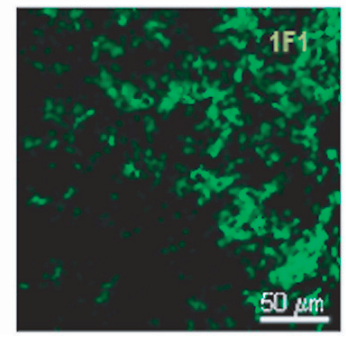

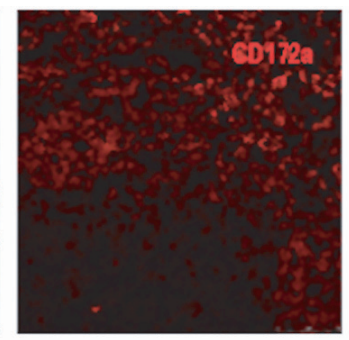
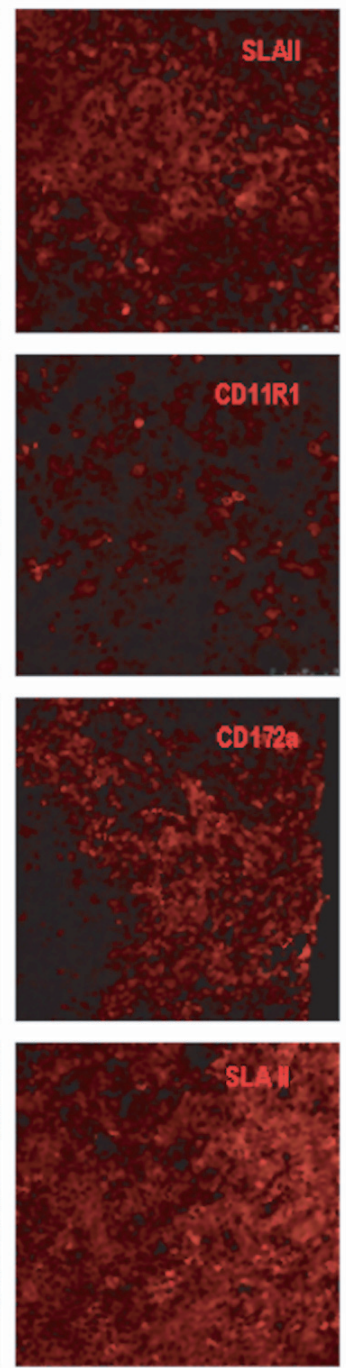
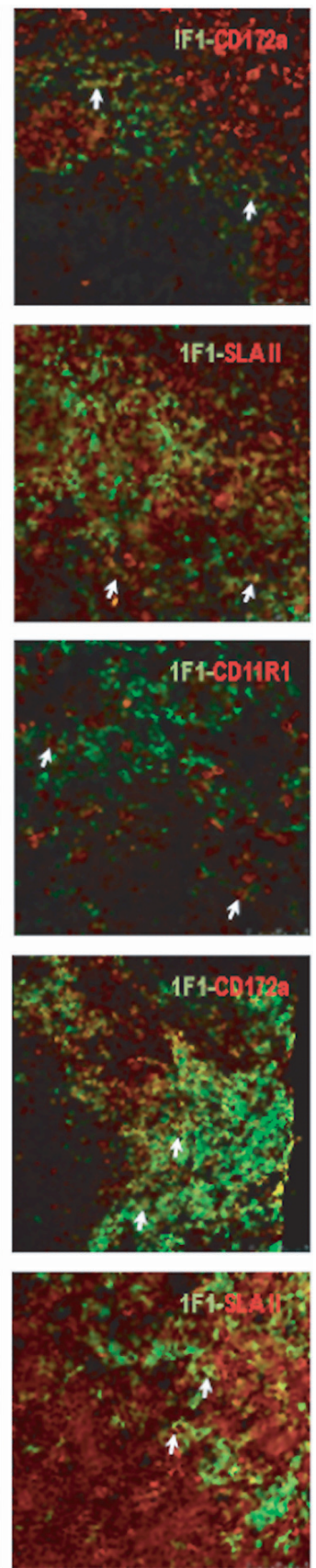

Figure 2. Double staining of spleen $(a-c)$ and mediastinal lymph node $(d, e)$ sections was carried out with $1 \mathrm{~F} 1 \mathrm{mAb}$ and $\mathrm{mAb}$ to CD172a (a, d), SLAII (b, e) and CD11R1 (c). Arrows point to representative cells co-expressing the indicated markers in the border between white and red pulp of the spleen, and in the subcapsular sinus of lymph nodes.

Page 6 of 15 (page number not for citation purpose) 


\section{A)}

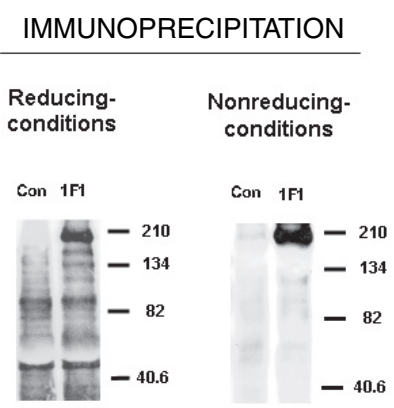

B)

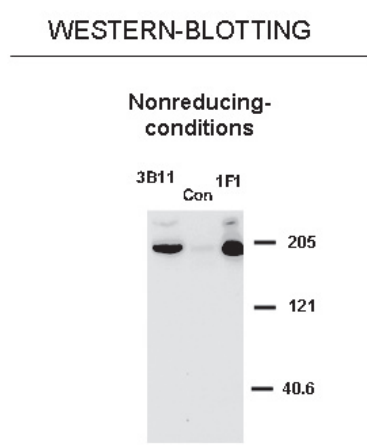

C)

SEQUENTIAL IMMUNOPRECIPITATION

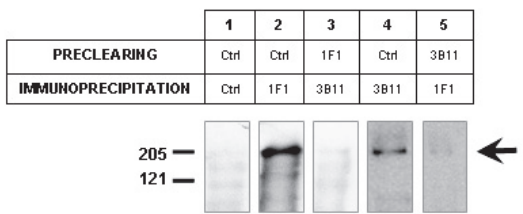

Figure 3. Biochemical characterization of antigen recognized by $1 \mathrm{~F} 1$ and $3 \mathrm{~B} 11 \mathrm{mAbs}$. (A) Lysates from biotin-labeled alveolar macrophages were immunoprecipitated with $1 \mathrm{~F} 1 \mathrm{mAb}$ or an irrelevant isotypematched control $\mathrm{mAb}$ (Con) and analyzed by 7.5\% SDS-PAGE under reducing and non-reducing conditions. Numbers in the right indicate position where MW markers ran. (B) Detection by western-blotting of the $1 \mathrm{~F} 1$ and 3B11 antigens on alveolar macrophage extracts subjected to 7.5\% SDS-PAGE under nonreducing conditions. (C) Immunoprecipitation analysis after preclearing. Lysates from biotin-labeled alveolar macrophages were immunoprecipitated with mAb $1 \mathrm{~F} 1$ and 3B11 after preclearing twice with the $\mathrm{mAb}$ indicated in the table. Arrow points the specific band, numbers in the left indicate position where MW markers ran. Results are representative of three independent experiments.

CD172a. SLAII molecules were clearly expressed on a subset of $1 \mathrm{~F} 1^{+}$cells. In the spleen a minor proportion of $1 \mathrm{~F} 1^{+}$cells also expressed CD11R1, a marker that has been associated with tissue DC.

MAb 3B11 was previously shown to recognize a single protein that migrates around $204 \mathrm{kDa}$ in SDS-PAGE under reducing conditions. Mab 1F1 precipitated, from lysates of biotin-labeled alveolar macrophages, a single protein of about $190 \mathrm{kDa}$ under nonreducing conditions, which became about $204 \mathrm{kDa}$ under reducing conditions in SDSPAGE (Fig. 3A). Western blotting on alveolar macrophage lysates shows that both $1 \mathrm{~F} 1$ and 3B11 $\mathrm{mAb}$ recognize a band of about $190 \mathrm{kDa}$ under non-reducing conditions (Fig. 3B). All these data suggest that both $\mathrm{mAb}$ react with the same antigen; to confirm this, alveolar macrophage lysates were pre-cleared with either $1 \mathrm{~F} 1$ or $3 \mathrm{~B} 11 \mathrm{mAb}$ followed by immunoprecipitation with the other $\mathrm{mAb}$. As shown in Figure 3C, clearance of lysates with $1 \mathrm{~F} 1$ removed the band precipitated by $3 \mathrm{~B} 11$, and clearance with $3 \mathrm{~B} 11 \mathrm{mAb}$ resulted in the removal of the band brought down by $1 \mathrm{~F} 1$ $\mathrm{mAb}$, establishing that these $\mathrm{mAb}$ recognize the same molecule.

To determine whether $1 \mathrm{~F} 1$ and $3 \mathrm{~B} 11$ $\mathrm{mAb}$ recognize the same epitope, crossblocking experiments were carried out. 1F1 $\mathrm{mAb}$ competitively blocked the binding of labeled $1 \mathrm{~F} 1$ but not that of $3 \mathrm{~B} 11$ to alveolar macrophages, as determined by flow cytometric analysis (Fig. 4). Likewise, 3B11 blocked the binding of labeled 3B11 but not 
Control

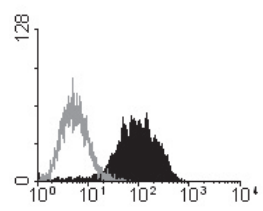

Control

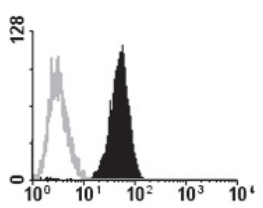

$1 \mathrm{~F} 1$

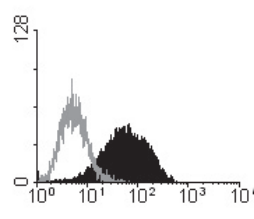

3B11

3B11

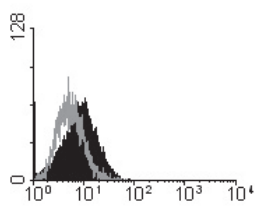

$1 \mathrm{~F} 1$
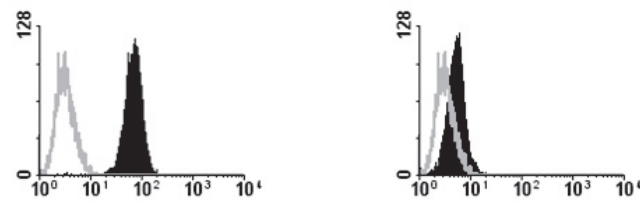

1F1

Figure 4. MAb 1F1 and 3B11 bind to two different epitopes on the Sn molecule. Black histograms show binding of labeled 3B11 or 1F1 mAb on alveolar macrophages after incubation with the indicated unlabeled antibodies. Grey histograms correspond to the negative control staining. Results are representative of at least two independent experiments using cells from different animals.

that of labeled 1F1. Altogether, these results indicate that $3 \mathrm{~B} 11$ and $1 \mathrm{~F} 1 \mathrm{mAb}$ react with different epitopes on the same molecule.

To identify the molecule recognized by $3 \mathrm{~B} 11$ and $1 \mathrm{~F} 1 \mathrm{mAb}$, it was purified from alveolar macrophage lysates by affinity chromatography on a column of 3B11 mAb-coupled Sepharose, and subjected to SDS-PAGE. The $190 \mathrm{kDa}$ band was cut out, digested with trypsin, and the resultant peptides resolved by HLPC and subjected to protein micro sequencing. Sequences from three tryptic peptides of the antigen were obtained (Tab. I). Computer searching of SwisProt, EMBL, and GeneBank databases ${ }^{1}$ showed that peptides were identical to those of pig Sn (see Tab. I). Only Sn from other species showed a significant homology to the swine 3B11 antigen peptides.

\subsection{Regulation of Sn expression on monocytes by cytokines or porcine serum}

Swine blood monocytes were magnetically isolated and cultured for 24 or $48 \mathrm{~h}$ in the presence of different stimuli or in medium

Table I. Comparison of partial peptide sequences between 3B11 Ag and porcine Sn.

\begin{tabular}{lcc}
\hline Peptide & Sequence & Identity (\%) \\
\hline $\begin{array}{l}\text { Peptide } 1 \\
\text { Porcine Sn }\end{array}$ & 928 WYRDGQPLQESTSATLRIAAI 948 & 100 \\
Peptide 2 & DLQPQDSGSYNFR & \\
Porcine Sn & 101 LLKDLQPQDSGSYNFRFEIS 119 & 100 \\
Peptide 3 & VNSDPPAQLR & \\
Porcine Sn & 998 LGLLLCRVNSDPPAQLRLLH 1018 & 100 \\
\hline
\end{tabular}

Page 8 of 15 (page number not for citation purpose) 
alone. After $24 \mathrm{~h}$ in culture with IFN- $\alpha$ some $80 \%$ of cells became positive for the expression of $\mathrm{Sn}$, and its expression remained at least for $48 \mathrm{~h}$. A lower enhancement of Sn expression was also achieved by culturing monocytes with porcine serum (30-40\% of positive cells). On the contrary, medium alone, IL4, IL10 or IFN- $\gamma$ did not cause a significant induction of Sn expression (Fig. 5).

\section{3. $1 \mathrm{~F} 1 \mathrm{mAb}$ is internalized upon binding}

To test the endocytic capacity of $\mathrm{Sn}$, alveolar macrophages were incubated with Alexa 488-labeled $1 \mathrm{~F} 1 \mathrm{mAb}$, for $30 \mathrm{~min}$ at $4{ }^{\circ} \mathrm{C}$ in FACS buffer without azide. After washing, cells were incubated at $37^{\circ} \mathrm{C}$ for 15 , 30 or $45 \mathrm{~min}$ to allow $\mathrm{mAb}$ internalization, and then treated or not for $15 \mathrm{~s}$ with a dissociating buffer containing $0.5 \%$ acetic acid, $0.5 \mathrm{M}$ $\mathrm{NaCl} \mathrm{pH} 2.8$ (low $\mathrm{pH}$ buffer) to remove the antibody bound to the cell surface. Cells identically treated, but in the presence of azide to prevent internalization, were used as controls. As shown in Figure 6, mAb to $\mathrm{Sn}$ was rapidly internalized. After $15 \mathrm{~min}$ of incubation at $37^{\circ} \mathrm{C}$, about $30 \%$ of the cells remained stained with the Alexa 488labeled $1 \mathrm{~F} 1 \mathrm{mAb}$ after treatment with the low $\mathrm{pH}$ buffer, and the amount of fluorescence located inside the cells increased for $45 \mathrm{~min}$. In contrast, in the presence of azide no fluorescence was detected after treatment with the low $\mathrm{pH}$ buffer. These results indicate that $1 \mathrm{~F} 1 \mathrm{mAb}$ was significantly and rapidly endocytosed by alveolar macrophages upon binding to $\mathrm{Sn}$.

\subsection{Targeting to $\mathrm{Sn}$ enhances $\mathrm{T}$ cell immune response}

Taking into account that $\mathrm{Sn}$ is an endocytic receptor expressed on APC, we wondered if antigen delivery to this receptor using the $1 \mathrm{~F} 1$ $\mathrm{mAb}$ as an Ag surrogate, could lead to a more efficient antigen presentation and generation of an antigen-specific $\mathrm{T}$ cell response. Pigs were immunized with a pool of mouse Ig and $\mathrm{T}$ cell proliferative response induced by anti$\mathrm{Sn} \mathrm{mAb} 1 \mathrm{~F} 1$ analyzed in vitro, and compared with that induced by an isotype-matched irrelevant mAb. When MoDC were used as APC, anti-Sn mAb induced proliferation of $\mathrm{T}$ cells at concentrations 100 -fold lower than the non-targeting control $\mathrm{mAb}$. Under these conditions, as few as $0.02 \mu \mathrm{g} / \mathrm{mL}$ of $1 \mathrm{~F} 1$ $\mathrm{mAb}$ induced a response equivalent to that of $2 \mu \mathrm{g} / \mathrm{mL}$ of the control mAb, as measured by ${ }^{3} \mathrm{H}$-thymidine uptake $(10593 \pm 731 \mathrm{cpm}$ versus $7414 \pm 681 \mathrm{cpm}$ ) (Fig. 7A). A similar result was obtained when monocytes cultured with IFN- $\alpha$ were used as APC. In this case $1 \mu \mathrm{g}$ of isotype-matched control $\mathrm{mAb}$ was needed to get a similar $\mathrm{T}$ cell response to that obtained with $0.01 \mu \mathrm{g}$ of $\mathrm{mAb} 1 \mathrm{~F} 1$ $(6969 \pm 1334 \mathrm{cpm}$ versus $6937 \pm 970 \mathrm{cpm})$ (Fig. 7B). Similar results were obtained with $\mathrm{mAb} 3 \mathrm{~B} 11$, whereas no proliferation was observed when cells from non immunized animals were treated with anti-Sn mAb (data not shown). These results indicate an efficient role of $\mathrm{Sn}$ in antigen uptake and/or processing in APC.

\section{DISCUSSION}

In this study we report the characterization of two mAb, $1 \mathrm{~F} 1$ and $3 \mathrm{~B} 11$, that react with porcine Sn. Confirmation of the specificity of these mAb comes from the sequence analysis of peptides derived from the antigen recognized by them.

The distribution of $\mathrm{Sn}$ on porcine leukocyte populations is close to that reported in humans [21, 37], being detected on subsets of macrophages mostly located in the border region between the white and red pulp and in the walls of sheathed capillaries or ellipsoids in the spleen, sinuses and periphery of follicles in lymph nodes, and Kupffer cells of the liver [4]. Moreover, like in humans [27], porcine MoDC express Sn. We also detected a subpopulation of Sn-positive cells within lymph node follicles that could be related to the DC described in mice that have the capacity to attract and provide antigenic stimulation to lymphocytes [1]. Porcine Sn is highly expressed in alveolar macrophages and, at low levels, in bone marrow macrophages [19]; in contrast, rat 
$24 \mathrm{~h}$

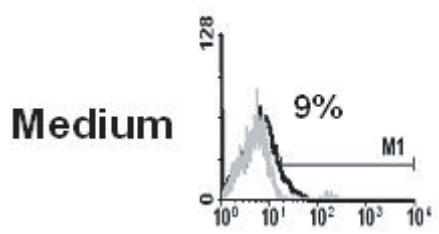

$48 \mathrm{~h}$
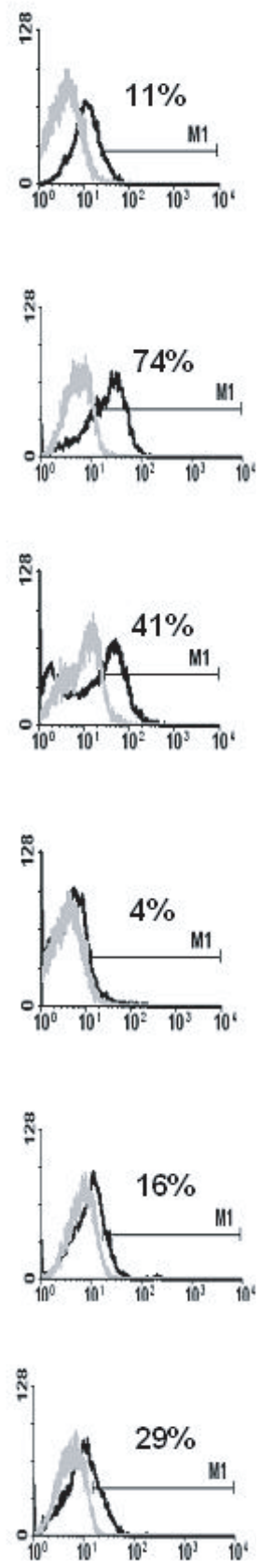

Figure 5. Regulation of Sn expression on blood monocytes by cytokines or porcine serum. Black histograms show the staining with $1 \mathrm{~F} 1 \mathrm{mAb}$ on monocytes subjected to the indicated stimuli after 24 or $48 \mathrm{~h}$. Grey histograms show binding of an irrelevant isotype-matched mAb. Results are representative of five independent experiments.

Page 10 of 15 (page number not for citation purpose) 


\section{+ azide \\ - low pH buffer}

(Maximum binding)

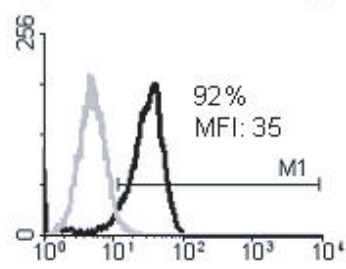

- azide

- low pH buffer

$15 \mathrm{~min}$

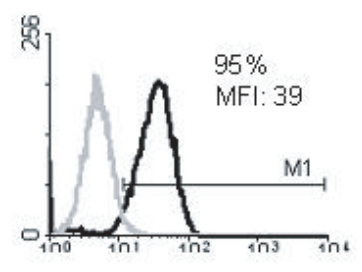

$30 \mathrm{~min}$

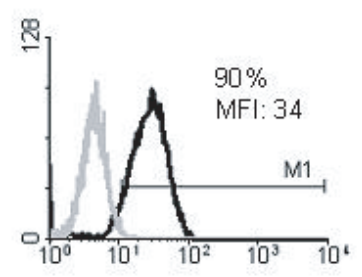

$45 \mathrm{~min}$

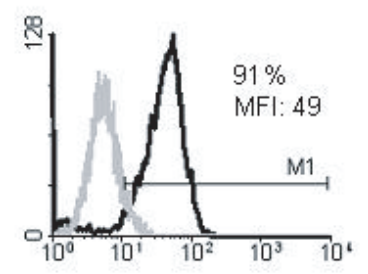

+ azide

+ low pH buffer

(anti-Sn mAb removed)

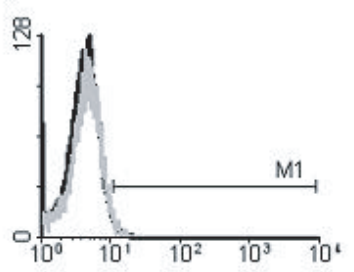

- azide

+ low pH buffer
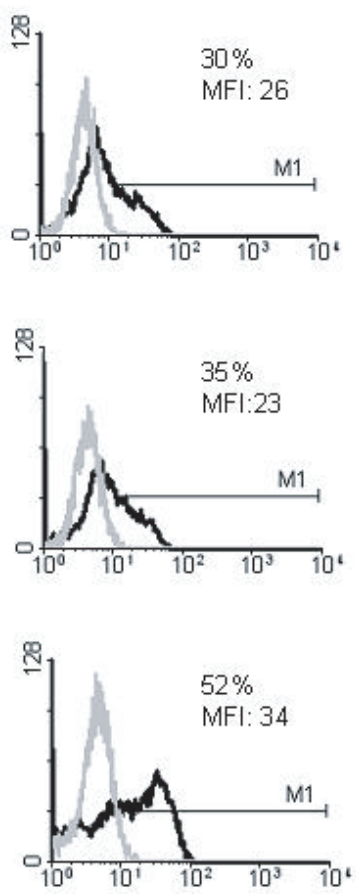

\section{Sialoadhesin}

Figure 6. Anti-Sn mAb $1 F 1$ is efficiently internalized in alveolar macrophages upon binding. Black histograms show $1 \mathrm{~F} 1$ - Alexa 488 fluorescence associated to the cells after treatments and $37^{\circ} \mathrm{C}$ incubation times indicated in the figure. Cells labeled with $1 \mathrm{~F} 1 \mathrm{mAb}$ at $4{ }^{\circ} \mathrm{C}$ in the presence of azide to block endocytosis, either untreated (maximum binding) or treated (background binding) with the low $\mathrm{pH}$ buffer were used as controls. Grey histograms show binding of an isotype-matched control mAb. Results are representative of three independent experiments. 
A)

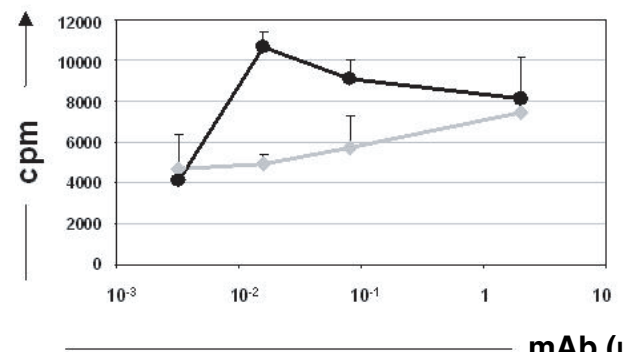

B)

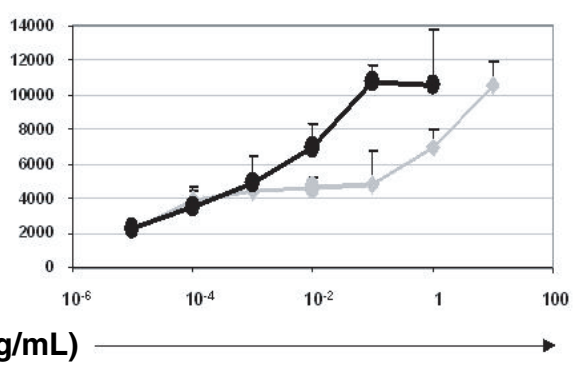

Figure 7. Antigen targeting to $\mathrm{Sn}$ enhances $\mathrm{T}$ cell immune responses. ${ }^{3} \mathrm{H}$-thymidine incorporation (cpm) in $\mathrm{T}$ cells from pigs immunized with mouse Ig, stimulated with $1 \mathrm{~F} 1 \mathrm{mAb}$ (black) or an isotype-matched control $\mathrm{mAb}$ (grey) at the indicated concentrations, using as APC: (A) MoDC or (B) Monocytes treated with IFN- $\alpha$ for $24 \mathrm{~h}$. The results are representative of three independent experiments.

and mouse alveolar macrophages are nearly negative for $\mathrm{Sn}$, while bone marrow resident macrophages are clearly positive $[8,41]$. This is not an unexpected finding since important differences have been reported among species in the regulation of $\mathrm{Sn}$ expression by cytokines, serum factors or glucocorticoids $[8,21,30,41]$. We show here that, like in humans and mice $[9,21]$, porcine monocytes do not express $\mathrm{Sn}$, but it can be up regulated to the levels found on macrophages by treating these cells with IFN- $\alpha$ and, at a lower extent, by culturing them with porcine serum. These results agree with those reported by other authors which have described that IFN- $\alpha$ treatment of porcine monocytes induces the expression of $\mathrm{Sn}$ [14].

Porcine $\mathrm{Sn}$ has been involved in the attachment and entry of PRRSV into alveolar macrophages [42]. The attachment of this virus to $\mathrm{Sn}$ is dependent on the sialic acid-binding activity of the N-terminal immunoglobulin domain of this receptor, but other domains might contribute to this interaction [15]. Competitive binding assays indicate that $\mathrm{mAb} 1 \mathrm{~F} 1$ and $3 \mathrm{~B} 11$ recognize two different epitopes on the $\mathrm{Sn}$ molecule since they do not block the binding of each other. Although further studies are needed to map these epitopes in more detail, previous unpublished work in our laboratory showed that mAb 3B11 can block the in vitro PRRSV infection of porcine alveolar macrophages. These mAb may therefore represent a valuable addition to the limited collection of reagents currently available for the analysis of PRRSV-cell interactions.

Targeting antigens to receptors expressed in APC is being evaluated as a strategy to enhance the immunogenicity of vaccines. Sn might be a good candidate for targeting antigens, as long as it is expressed in APC and has endocytic capacity. Indeed, we show that a significant amount of Alexa 488 labeled $\mathrm{mAb} 1 \mathrm{~F} 1$ was internalized upon binding to alveolar macrophages. In addition, we see that a portion of $\mathrm{Sn}$-positive cells in lymph nodes and spleen co-express SLAII molecules and therefore they are presumably capable of antigen presentation. A few Sn-positive cells also express CD11R1, a marker that has been associated to tissue DC in the pig [2,22]. Moreover, the anatomical location of Sn-positive cells in these organs is suitable for trapping blood and lymph-borne antigens. In mice, Sn-positive cells in lymph nodes, spleen and liver are capable of antigen uptake and presentation of processed peptides to $\mathrm{T}$ cells $[1,32,40]$. Moreover, Sn-positive subcapsular sinus macrophages in lymph nodes have been shown to capture particulate antigens, such as viruses, arriving via the lymph from the site of infection, and retain them unprocessed for the efficient presentation and activation of 
follicular B cells, leading to the initiation of humoral immune responses $[6,26]$.

We took advantage of immunogenicity of mouse immunoglobulins (Ig) in pigs to set up a model for the analysis of the capacity of mouse $\mathrm{mAb}$ to target antigen. Thus, using $\mathrm{T}$ lymphocytes from animals that had been immunized with a pool of mouse Ig as responder cells, and MoDC or monocytes cultured with IFN- $\alpha$ as APC, we compared, in vitro, the proliferative response induced by anti-Sn mAb (1F1) with that of a control mAb. MAb 1F1 induced recall $T$ cell proliferative responses at concentrations 100-fold lower than a non-targeting control $\mathrm{mAb}$, indicating that targeting $\mathrm{Ag}$ to $\mathrm{Sn}$ is an effective way to increase immunogenicity of Ag. These data suggest that Sn ligands efficiently gain access to the major histocompatibility complex processing and presentation pathways. Recently, it has been reported that in vivo targeting Siglec-H, another member of the Siglec receptor family, is a useful way for delivering antigens to plasmacytoid DC precursors for cross-presentation [43]. Sn and other Siglecs can interact with sialic acids on different pathogens, increasing their binding to target cells and contributing to their endocytosis or phagocytosis $[5,15,25,31]$. The data presented here agree with the hypothesis that Siglec-dependent uptake of pathogens could benefit the host by promoting pathogen destruction and antigen presentation. Future in vivo experiments will test the capacity of antibody mediated targeting of $\mathrm{Sn}$ to induce antigen-specific primary $\mathrm{T}$ cell responses.

Acknowledgements. This work was supported by grants AGL2004-4074 and CSD2006-0007 from Spanish Ministry of Education and Science. C. Revilla was recipient of a RyC contract of the Spanish Ministry of Education and Science, and T. Poderoso of a fellowship of the Generalitat de Catalunya.

\section{REFERENCES}

[1] Berney C., Herren S., Power C.A., Gordon S., Martínez-Pomares L., Kosco-Vilbois M.H., A member of the dendritic cell family that enters B cell follicles and stimulates primary antibody responses identified by a mannose receptor fusion protein, J. Exp. Med. (1999) 190:851-860.
[2] Bimczok D., Post A., Tschernig T., Rothkötter H.-J., Phenotype and distribution of dendritic cells in the porcine small intestinal and tracheal muchosa and their spatial relationship to epithelial cells, Cell Tissue Res. (2006) 325:461-468.

[3] Bullido R., Alonso F., Gómez del Moral M., Ezquerra A., Álvarez B., Ortuño E., Domínguez J., Monoclonal antibody $2 \mathrm{~F} 4 / 11$ recognizes the $\alpha$ chain of a porcine $\beta 2$ integrin involved in adhesion and complement mediated phagocytosis, J. Immunol. Methods (1996) 195:125-134.

[4] Bullido R., Gómez del Moral M., Alonso F., Ezquerra A., Zapata A., Sánchez C., et al., Monoclonal antibodies specific for porcine monocytes/macrophages: macrophage heterogeneity in the pig evidenced by the expression of surface antigens, Tissue Antigens (1997) 49:403-413.

[5] Carlin A.F., Lewis A.L., Varki A., Nizet V., Group B Streptococcal sialic acids interact with Siglecs (immunoglobulin-like lectins) on human leukocytes, J. Bacteriol. (2007) 189:1231-1237.

[6] Carrasco Y.R., Batista F.D., B cells acquire particulate antigen in a macrophage-rich area at the boundary between the follicle and the subcapsular sinus of the lymph node, Immunity (2007) 27:160-171.

[7] Chaplin P.J., De Rose R., Boyle J.S., McWaters P., Kelly J., Tennent J.M., et al., Targeting improves the efficacy of a DNA vaccine against Corynebacterium pseudotuberculosis in sheep, Infect. Immun. (1999) 67:6434-6438.

[8] Crocker P.R., Hill M., Gordon S., Regulation of a murine macrophage haemagglutinin (sheep erythrocyte receptor) by a species-restricted serum factor, Immunology (1988) 65:515-522.

[9] Crocker P.R., Gordon S., Mouse macrophage hemagglutinin (sheep erythrocyte receptor) with specificity for sialylated glycoconjugated characterized by a monoclonal antibody, J. Exp. Med. (1989) 169:13331346.

[10] Crocker P.R., Werb Z., Gordon S., Bainton D.F., Ultrastructural localization of a macrophagerestricted sialic acid binding hemagglutinin, SER, in macrophage-hematopoietic cell clusters, Blood (1990) 76:1131-1138.

[11] Crocker P.R., Freeman S., Gordon S., Kelm S., Sialoadhesin binds preferentially to cells of the granulocytic lineage, J. Clin. Invest. (1995) 95: 635643.

[12] Crocker P.R., Paulson J.C., Varki A., Siglecs and their roles in the immune system, Nat. Rev. Immunol. (2007) 7:255-266. 
[13] Damoiseaux J.G., Döpp E.A., Dijkstra C.D., Cellular binding mechanism on rat macrophages for syalylated glycoconjugates, inhibited by the monoclonal antibody ED3, J. Leukoc. Biol. (1991) 49: 434-441.

[14] Delputte P.L., Van Breedam W., Barbé F., Van Reeth K., Nauwynck H.J., INF- $\alpha$ treatment enhances porcine arterivirus infection of monocytes via upregulation of the porcine arterivirus receptor sialoadhesin, J. Interferon Cytokine Res. (2007) 27:757-766.

[15] Delputte P.L., Van Breedam W., Delrue I., Oetke C., Crocker P.R., Nauwynck H.J., Porcine arterivirus attachment to the macrophage-specific receptor sialoadhesin is dependent on the sialic acidbinding activity of the N-terminal immunoglobulin domain of sialoadhesin, J. Virol. (2007) 81:95469550 .

[16] Dijkstra C.D., Döpp E.A., Joling P., Kraal G., The heterogeneity of mononuclear phagocytes in lymphoid organs: distinct macrophage subpopulations in the rat recognized by monoclonal antibodies ED1, ED2 and ED3, Immunology (1985) 54:589-599.

[17] Domenech N., Rodríguez-Carreño M.P., Filgueira P., Alvarez B., Chamorro S., Domínguez J., Identification of porcine macrophages with monoclonal antibodies in formalin-fixed, paraffin-embedded tissues, Vet. Immunol. Immunopathol. (2003) 94:77-81.

[18] Drew D.R., Boyle J.S., Lew A.M., Lightowlers M.W., Chaplin P.J., Strugnell R.A., The comparative efficacy of CTLA-4 and L-selectin targeted DNA vaccines in mice and sheep, Vaccine (2001) 19: 44174428.

[19] Ezquerra A., Revilla C., Alvarez B., Pérez C., Alonso F., Domínguez J., Porcine myelomonocytic markers and cells populations, Dev. Comp. Immunol. (2008) doi: 10.1016/j.dci.2008.06.002.

[20] Gonzalez S., Mendoza C., Sánchez-Vizcaino J.M., Alonso F., Inhibitory effect of African swine fever virus on lectin-dependent swine lymphocyte proliferation, Vet. Immunol. Immunopathol. (1990) 26:71-80.

[21] Hartnell A., Steel J., Turley H., Jones M. Jackson D.G., Grocker P.R., Characterization of human sialoadhesin, a sialic acid binding receptor expressed by resident and inflammatory macrophage populations, Blood (2001) 97:288-296.

[22] Haverson K., Singha S., Stokes C.R., Bailey M., Professional and non-professional antigen-presenting cells in the porcine small intestine, Immunology (2000) 101:491-500.

[23] Jiang H.-R., Hwenda L., Makinen K., Oetke C., Crocker P.R., Forrester J.V., Sialoadhesin promotes the inflammatory response in experimental autoimmune uveoretinitis, J. Immunol. (2006) 177:2258-2264.

[24] Johansson E., Domeika K., Berg M., Alm G.V., Fossum C., Characterization of porcine monocytesderived dendritic cells according to their cytokine profile, Vet. Immunol. Immunopathol. (2003) 91:183197.

[25] Jones C., Virji M., Crocker P.R., Recognition of sialylated meningococcal lipopolysaccharide by siglecs expressed on myeloid cells leads to enhanced bacterial uptake, Mol. Microbiol. (2003) 49:12131225 .

[26] Junt T., Moseman E.A., Iannacone M., Massberg S., Lang P.A., Boes M., et al., Subcapsular sinus macrophages in lymph nodes clear lymph-borne viruses and present them to antiviral B cells, Nature (2007) 450:110-114.

[27] Kirchberger S., Majdic O., Steinberger P., Blüml S., Pfistershammer K., Zlabinger G., et al., Human rhinoviruses inhibit the accessory function of dendritic cells by inducing sialoadhesin and B7-H1 expression, J. Immunol. (2005) 175:1145-1152.

[28] Kölher G., Milstein C., Continuous cultures of fused cells secreting antibody of predefined specificity, Nature (1975) 256:495-497.

[29] Manoj S., Griebel P.J., Babiuk L.A., Van Drunen Little-van den Hurk S., Targeting with bovine CD154 enhances humoral immune responses induced by a DNA vaccine in sheep, J. Immunol. (2003) 170:989996.

[30] McWilliam A.S., Tree P., Gordon S., Interleukin 4 regulates induction of sialoadhesin, the macrophage sialic acid-specific receptor, Proc. Natl. Acad. Sci. USA (1992) 89:10522-10526.

[31] Monteiro V.G., Lobato C.S., Silva A.R., Medina D.V., de Oliveira M.A., Seabra S.H., et al., Increased association of Trypanosoma cruzi with sialoadhesin positive mice macrophages, Parasitol. Res. (2005) 97:380-385.

[32] Müerköster S., Rocha M., Crocker P.R., Schirrmacher V., Umansky V., Sialoadhesin-positive host macrophages play an essential role in graftversus-leukemia reactivity in mice, Blood (1999) 93:4375-4386.

[33] Munday J., Floyd H., Crocker P.R., Sialic acid binding receptors (siglecs) expressed by macrophages, J. Leukoc. Biol. (1999) 66: 705-711.

[34] Oetke C., Vinson M.C., Jones C., Crocker P.R., Sialoadhesin-deficient mice exhibit subtle changes in B- and T-cell populations and reduced immunoglobulin M levels, Mol. Cell. Biol. (2006) 26:1549-1557. 
[35] Paquette R.L., Hsu N.C., Kiertscher S.M., Park A.N., Tran L., Roth M.D., Glaspy J.A., Interferonalpha and granulocyte-macrophage colony-stimulating factor differentiate peripheral blood monocytes into potent antigen-presenting cells, J. Leukoc. Biol. (1998) 64:358-367.

[36] Pulliam L., Sun B., Rempel H., Invasive chronic inflammatory monocytes phenotype in subjects with high HIV-1 viral load, J. Neuroimmunol. (2004) 157:93-98.

[37] Steiniger B., Barth P., Herbst B., Hartnell A., Crocker P.R., The species-specific structure of microanatomical compartments in the human spleen: strongly sialoadhesin -positive macrophages occur in the perifollicular zone, but not in the marginal zone, Immunology (1997) 92:307-316.

[38] Tachedjian M., Boyle J.S., Lew A.M., Horvatic B., Scheerlinck J.P., Tennent J.M., Andrew M.E., Gene gun immunization in a preclinical model is enhanced by B7 targeting, Vaccine (2003) 21:2900-2905.

[39] Tacken P.J., De Vries J.M., Torensma R., Figdor C.G., Dendritic-cell immunotherapy: from ex vivo loading to in vivo targeting, Nat. Immunol. Rev. (2007) 7:790-802.

[40] Umansky V., Beckhove P., Rocha M., Kruger A., Crocker P.R., Schirrmacher V., A role for sialoadhesinpositive tissue macrophages in host resistance to lymphoma metastasis in vivo, Immunology (1996) 87:303-309.

[41] Van den Berg T.K., Van Die I., Lavette C.R., Döpp E.A., Smit L.D., Van der Meide P.H., et al., Regulation of sialoadhesin expression on rat macrophages. Induction by glucocorticoids and enhancement by IFN- $\beta$, IFN- $\gamma$, IL- 4 and lipopolysaccharide, J. Immunol. (1996) 157:3130-3138.

[42] Vanderheijden N., Delputte P.L., Favoreel H.W., Vandekerckhove J., Van Damme J., van Woensel P.A., Nauwynck H.J., Involvement of sialoadhesin in entry of porcine reproductive and respiratory syndrome virus into porcine alveolar macrophages, J. Virol. (2003) 77:8207-8215.

[43] Zhang J., Raper A., Sugita N., Hingorani R., Salio M., Palmowski M.J., et al., Characterization of Siglec$\mathrm{H}$ as a novel endocytic receptor expressed on murine plasmacytoid dendritic cell precursors, Blood (2006) 107:3600-3608. 